\title{
GEOMORPHOLOGICAL CHARACTERIZATION OF THE TARUMÃ-AÇÚ BASIN, AMAZONAS, BRAZIL
}

\author{
MATHEUS SILVEIRA DE QUEIROZ \\ Mestrando em Geografia. Universidade Federal do Amazonas ${ }^{1}$ \\ msdq.geo16@uea.edu.br
}

JOSÉ ALBERTO LIMA DE CARVALHO

Doutor em Geografia. Universidade Federal do Amazonas - UFAM ${ }^{1}$

albertogeografo@gmail.com

\begin{abstract}
The aim of this paper was to analyze the geomorphology of the Tarumã-Açú basin according to morphometric and tectonic parameters to understand the current geomorphological dynamics of the basin. Morphometric analysis indicated a low tendency to erosion in the Basin. The flat slope is located near the mouth of the Tarumã-Açú river, the Strong Wavy and Mountainous slopes (20$75 \%$ ) indicate terraces and dividers and most of the basin is characterized by small and medium hills (3$20 \%)$. The basin has a strong structural control represented by a Strike-Slip Fault that controls the Tarumã-Açú River and the tributaries of left bank have lineaments and parallelism that may indicate tectonic control (probably Dip-Slip Faults) in an en echelon system. It is also noted that the basin underwent tectonic tilting to the west, possibly indicating tectonic influence during the Cenozoic.
\end{abstract}

KEY WORDS: Morphotectonics; Tarumã-Açú Basin; Geomorphological Analysis.

\section{CARACTERIZAÇÃO GEOMORFOLÓGICA DA BACIA DO TARUMÃ-AÇÚ, AMAZONAS,} BRASIL

RESUMO: O objetivo deste artigo foi analisar o relevo da Bacia do Tarumã-Açú de acordo com parâmetros morfométricos e tectônicos, buscando entender a dinâmica geomorfológica atual da bacia. A análise morfométrica indicou uma baixa tendência à erosão na Bacia, as declividades planas localizamse próximas à foz do rio Tarumã-Açú, as declividades Forte Ondulada e Montanhosa (20-75\%) indicam terraços e divisores e a maior parte da bacia é caracterizada por pequenas e médias colinas (3-20\%). A bacia possui um forte controle estrutural representado por uma falha transcorrente que controla o rio Tarumã-Açú e os tributários da margem esquerda possuem lineamentos e paralelismo que podem indicar controle tectônico (provavelmente falhas normais ou inversas) em um sistema en echelon. Notase também que a bacia sofreu basculamento para oeste, possivelmente indicando influência tectônica durante o Cenozoico.

PALAVRAS-CHAVE: Morfotectônica; Bacia do Tarumã-Açú; Análise do Relevo.

\section{CARACTERIZACIÓN GEOMORFOLÓGICA DE LA CUENCA TARUMÃ-AÇÚ, AMAZONAS,} BRASIL

RESUMEN: El propósito de este artículo fue analizar la geomorfología de la cuenca Tarumã-Açú según parámetros morfométricos y tectónicos para comprender la dinámica geomorfológica actual de la cuenca. El análisis morfométrico del relieve indicó una baja tendencia a la erosión en la Cuenca, lases pendientes planas se encuentran cerca de la desembocadura del río Tarumã-Açú y las pendientes Fuerte Onduladas y Montañosas (20-75\%) indican terrazas y divisiones. La mayor parte de la cuenca se caracteriza por colinas pequeñas y medianas (3-20\%). La cuenca tiene un fuerte control estructural representado por falla de desplazamiento de rumbo que controla el río Tarumã-Açú y los afluentes de la margen izquierda tienen lineamientos y paralelismo que pueden indicar un control tectónico (probablemente fallas normales o inversas) en un sistema en echelon. También se observa que la cuenca ha experimentó una inclinación tectónica hacia el oeste, lo que posiblemente indica una influencia tectónica durante el Cenozoico.

PALABRAS-CLAVE: Morfotectónica; Cuenca del Tarumã-Açú; Análisis Geomorfológico.

${ }^{1}$ Endereço para correspondência: Av. General Rodrigo Octávio, 6200, Coroado I, Setor Norte. CEP: 69080-900 Manaus, AM - Brasil

Matheus S. de Queiroz, José Alberto L. de Carvalho. Geomorphological characterization of the Tarumã-Açú basin, Amazonas, Brazil Brazilian Geographical Journal: Geosciences and Humanities research medium, Ituiutaba, v. 11, n. 2, p. 113-125, ago./dez. 2020 


\section{INTRODUCTION}

The landscape of the Amazon basin underwent major changes during the Cenozoic. The integrated performance of tectonic movements, active until today (responsible for uplift and subsidence in several Amazonian lands and for drainage reorganization), and climaticenvironmental variations, since the Paleogene, indicate the morphogenetic changes in the Amazon basin (STERNBERG, 1950; MEIS, 1971; TRICART, 1977; COSTA, et al., 1978; HOORN et al., 1995; COSTA et al., 1996; HORBE et al., 2001; COSTA, 2002; FRANZINELLI and IGREJA, 2002; BEZERRA, 2003; LATRUBESSE and FRANZINELLI, 2005; SILVA, 2005; MAPES et al., 2006).

The geomorphological forms originated from the changes that occurred in the drainage basin indicate landscapes influenced by neotectonics and erosive processes (IGREJA, 1999; FRANZINELLI and IGREJA, 2002; VIEIRA, 2008). The study of basins is important to understand the changes in the relief and to characterize the geomorphological processes (STEVAUX and LATRUBESSE, 2017). Therefore, the study area of this paper was the TarumãAçú basin. The basin is located in Central Amazonia, on the territorial limits of the Manaus Municipality in the Amazonas State (Figure 1). The basin has an area of $1362.5 \mathrm{~km}^{2}$, a perimeter of $345.5 \mathrm{~km}$ and is characterized by the typical geomorphology of the Lower Negro River with geomorphological and structural conditions that are part of a larger system of geological structures that occur in the Amazon basin.

Figure 1 - Location of the Tarumã-Açú Basin, Brazil

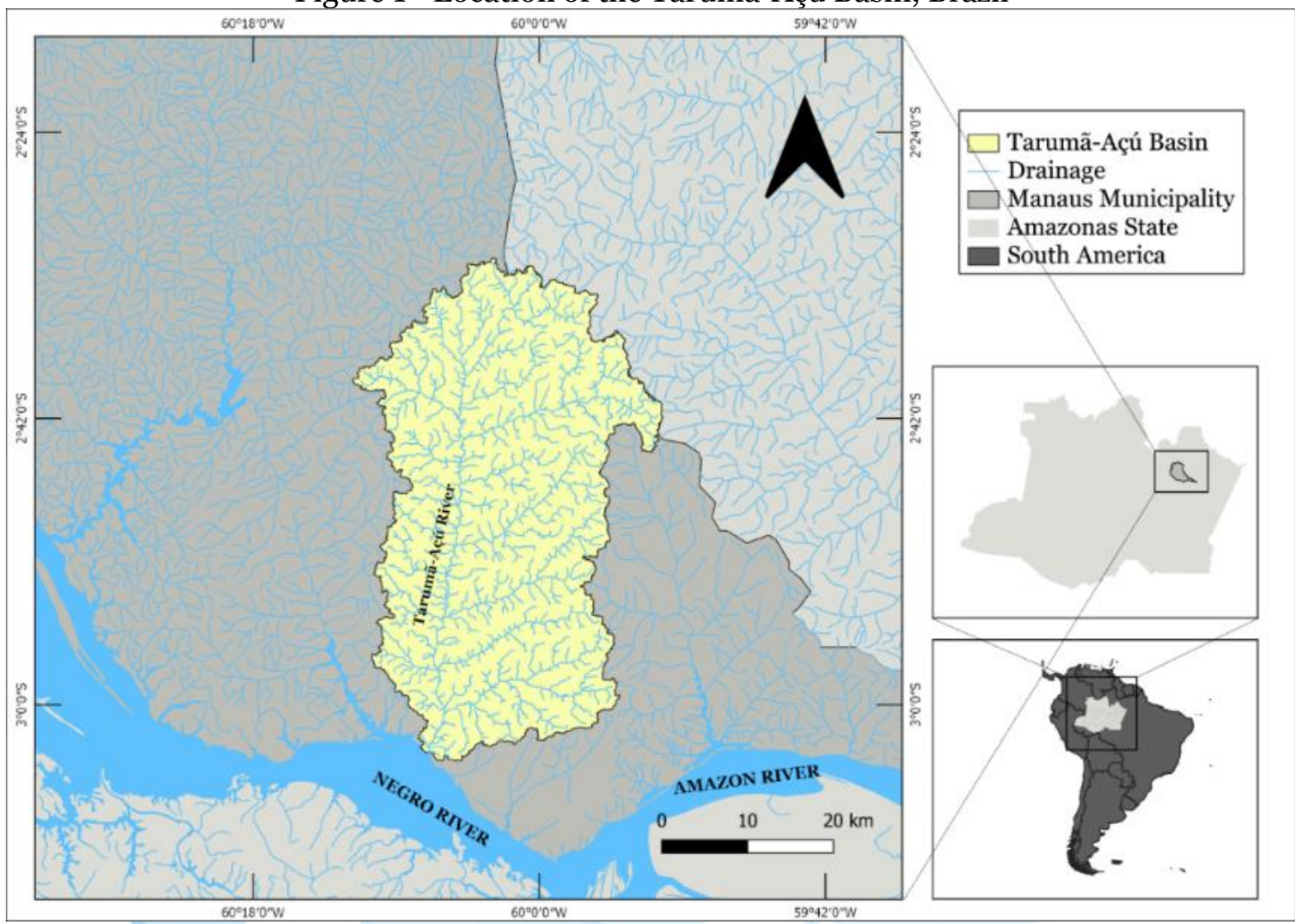

Source: the authors, 2020.

The aim of this paper was to analyze the geomorphology of the Tarumã-Açú basin according to morphometric and tectonic parameters to understand the current basin geomorphological dynamics. 


\section{REGIONAL SETTING}

The lower Negro River region is located in the sedimentary basin of Amazonas, which has an area of $620,000 \mathrm{~km}^{2}$ and elongated linear shape in the direction ENE-WSW (FERREIRA et al., 2015). Deposition in the Amazon Basin begins in the Neo-Ordovician with the glacial to marine sedimentation of the Trombetas Group. The region of the Tarumã-Açú Basin is located in the Javari group (Alter do Chão Formation and Solimões Formation), which brings together fluvial-lacustrine clastic that are part of the Cretaceous - Tertiary (Paleogene and Neogene) boundary whose evolution is linked to the Andean orogenic activity (REIS et al., 2006).

Alter do Chão Formation predominates in the Tarumã-Açú basin area, which was defined by Kistler (1954) with a composition of reddish sandstones, mudstones, conglomerates and intraformational stratigraphic gaps dated to the Late Cretaceous-Paleogene. These characteristics are associated with deposition environments by river, lake or delta systems (ALBUQUERQUE, 1922, KISTLER, 1954; CAPUTO, 1984; REIS et al., 2006; HOORN et al., 2010).

The geomorphology of the Manaus municipality has features associated with geological evolution during the Cenozoic. The relief is conditioned by geological structures in a NW-SE and NE-SW direction, whose trends correspond to the orientation of the main drainages in the Central Amazon region. However, there are structures that are conditioned in the N-S and E$\mathrm{W}$ directions that are equally important in the partitioning and evolution of the relief (SILVA, 2005).

The Amazon basin region has a strong tectonic influence (COSTA et al., 1996; IGREJA, 1999) and the main rivers of the Amazon basin have strong structural control, conditioning the morphology of these rivers (SILVA and ROSSETI, 2009). According to Franzinelli et al. (1999) the modern neostructural directions of the Amazon transcurrent system is for Amazon River: N8oE; Solimões River: N6oW; Negro River: N45W; Madeira River: N5oE.

According to Latrubesse and Franzinelli (2005, p.378) "the fluvial belt of the Negro River shows strong structural control". In the lower Negro River, Sternberg (1950) identified a parallelism between the main rivers in the region, attributing this to possible tectonic control. Franzinelli and Igreja (1990; 2002) proposed a tectonic model for the lower Negro River, indicating that the region is controlled by two distinct neostructural domains that control the river's physiography: Normal Fault Domain and Dextral Fault Domain (Figure 2). It is worth mentioning that the authors do not present structural data for the elaboration of the model for the lower Negro River, using only remote sensing data.

Several authors (see FRANZINELLI and IGREJA, 1990, 2002; FRANZINELLI et al., 1999; LATRUBESSE and FRANZINELLI, 2005; SILVA, 2005) investigated the Tarumã-Açú basin and indicate strong structural control that influences landscape morphology and controls drainage (Figure 2). The modern neotectonic direction of the Tarumã-Açú River is N10E (FRANZINELLI et al., 1999) and is controlled by a Strike-Slip Fault (FRANZINELLI and IGREJA, 1990; 2002; LATRUBESSE and FRANZINELLI, 2005). According to Franzinelli and Igreja (1990) in the tributaries of the Tarumã-Açú River left bank there is an en echelon system, represented by the lineaments in the igarapés: Bolivia, Mariano, Leão, Santo Antônio, Santa Rosa and Preguiça.

The configurations of the different biomes result from the interrelations among these neotectonic directions. The aquatic biome characterized by the "igapó" area is the result of lowered neotectonic environments (negative relief), with subsided areas, inclined to flooding or to sedimentation. Biomes with terrestrial characteristics (terra firme, islands, almondshaped terraces, sigmoidal plateaus, aligned or irregular headwaters), occur in the geotectonic directions NE-SW and NW-SE of the geomorphologic lifted regions (FRANZINELLI et al., 1999). 
Figure 2 - Neotectonic model of Lower Negro River

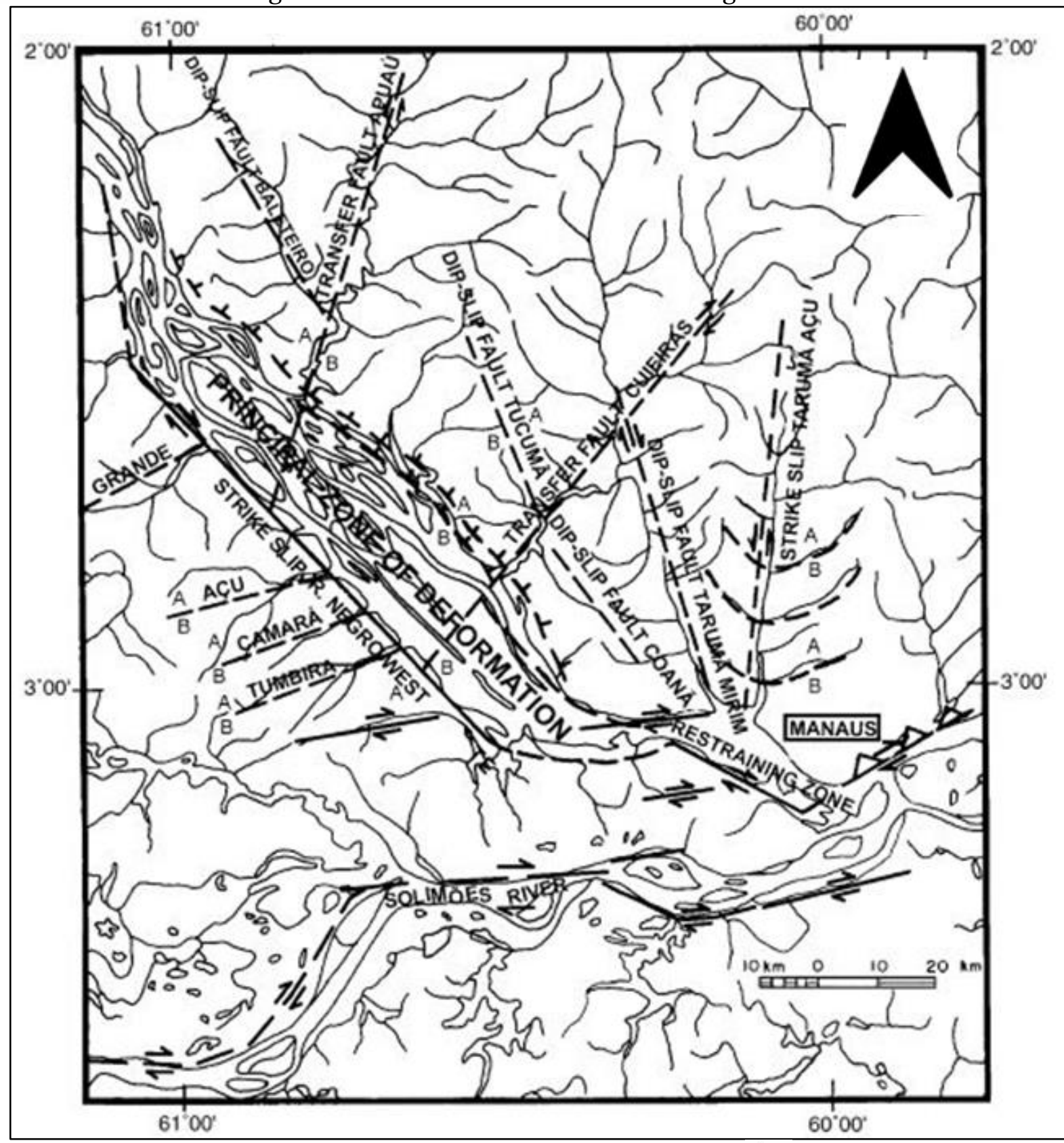

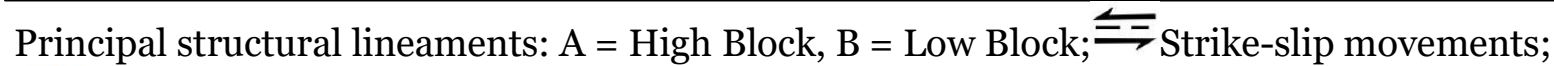

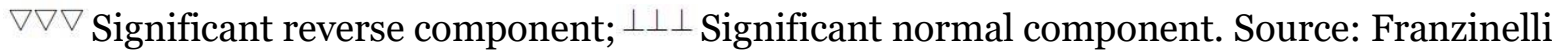
and Igreja (2002).

\section{METHODOLOGY}

Morphometric parameters are important for the quantitative analysis of geomorphology (MORISAWA, 1968; STEVAUX and LATRUBESSE, 2017). Therefore, we have defined some parameters to analyze the Tarumã-Açú basin: Drainage Density $\left(D_{d}\right)$; Constant of Channel Maintenance (C); Relative Relief $(\mathrm{H})$; Basin Relief Ratio $\left(\mathrm{R}_{\mathrm{h}}\right)$; Ruggedness Number $\left(\mathrm{R}_{\mathrm{n}}\right)$; Stream Frequency $\left(\mathrm{F}_{\mathrm{s}}\right)$; Infiltration Number $\left(\mathrm{I}_{\mathrm{g}}\right)$, Slope and Hypsometry. 
Drainage Density is the parameter that controls the drainage efficiency of the basin, important for classifying hydrological and relief parameters (MORISAWA, 1968; STEVAUX and LATRUBESSE, 2017). Horton (1932; 1945) defined the drainage density as the quotient between the total stream length and the drainage area (Equation 1):

$\mathrm{D}_{\mathrm{d}}=\frac{\sum \mathrm{L}_{\mu}}{\mathrm{A}_{\mathrm{d}}}$

Where $D_{d}$ is Drainage Density. $L_{\mu}$ is total stream length. $A_{d}$ is Drainage Area.

The Stream Frequency is important for, like drainage density, measuring the degree of dissection of a basin (MORISAWA, 1968). The Stream Frequency is the number of channels per unit area (Equation 2) (CHANDRASHEKAR et al., 2015).

$\mathrm{F}_{\mathrm{s}}=\frac{\sum \mathrm{N}_{\mu}}{\mathrm{A}_{\mathrm{d}}}$

Where $F_{s}$ is Stream Frequency. $N_{\mu}$ is total number of channels. $A_{d}$ is Drainage Area.

The Constant of Channel Maintenance indicates the area necessary to develop and maintain a drainage channel of a given extension (MORISAWA, 1968). Schumm (1956) determined that the Constant of Channel Maintenance is the quotient between the drainage area and total stream length (Equation 3), having an inverse relationship with the drainage density (STEVAUX and LATRUBESSE, 2017).

$\mathrm{C}=\frac{\mathrm{A}_{\mathrm{d}}}{\sum \mathrm{L}_{\mu}}$

Where $\mathrm{C}$ is Constant of Channel Maintenance. $\mathrm{A}_{\mathrm{d}}$ is Drainage Area. $\mathrm{L}_{\mu}$ is total stream length.

The Basin Relative Relief corresponds to the altimetric difference between the basin baseline level and the highest topographic point (CHRISTOFOLETTI, 1981; MUÑOZ and VALERIANO, 2011). Represented by equation 4:

$\mathrm{H}=\mathrm{Z}-\mathrm{Z}$

Where $\mathrm{H}$ is relative relief. $\mathrm{Z}$ is maximum basin altitude. $\mathrm{z}$ is minimum basin altitude.

The Basin Relief Ratio considers the relationship between the Relative Relief and the maximum length of the basin (SCHUMM, 1956). Represented by equation 5:

$\mathrm{R}_{\mathrm{r}}=\frac{\mathrm{H}}{\mathrm{L}_{\mathrm{h}}}$

Where $R_{r}$ is Basin Relief Ratio. $H$ is relative relief. $L_{h}$ is maximum basin length.

According to Christofoletti (1980, p. 121) "the ruggedness number combines the qualities of slope and length of the slopes, with the drainage density [...]". Represented by equation 6:

$\mathrm{R}_{\mathrm{n}}=H \mathrm{HD}_{\mathrm{d}}$

Where $R_{n}$ is ruggedness number. $H$ is relative relief. $D_{d}$ is Drainage Density

The Infiltration Number is defined by the product of Drainage Density and Stream

Frequency (Equation 7) (SURESH et al., 2015):

$I_{g}=D_{d} F_{s}$

Where $I_{g}$ is Infiltration Number.

Matheus S. de Queiroz, José Alberto L. de Carvalho. Geomorphological characterization of the Tarumã-Açú basin, Amazonas, Brazil Brazilian Geographical Journal: Geosciences and Humanities research medium, Ituiutaba, v. 11, n. 2, p. 113-125, ago./dez. 2020 
To calculate the slope (\%), the formulas proposed by Horn (1981) were used. The data were spatialized according to the classification of the Brazilian Agricultural Research Corporation - EMBRAPA (2006), which groups the slope into six classes: flat, smooth wavy, wavy, strong wavy, mountainous and steep (Table 1), Hypsometry was also calculated in six classes. For this, the digital elevation model provided by the SRTM (Shuttle Radar Topography Mission) (https://earthexplorer.usgs.gov/) was used and worked on the Quantum-GIS.

\begin{tabular}{cc}
\multicolumn{2}{c}{ Table 1 - Slope Classes } \\
Slope (\%) & Relief \\
\hline $0-3$ & Flat \\
$3-8$ & Smooth wavy \\
$8-20$ & Wavy \\
$20-45$ & Strong Wavy \\
$45-75$ & Mountainous \\
$75-$ & Steep \\
\hline Source: EMBRAPA (2006).
\end{tabular}

The mean slope of the main channel of the basin was calculated according to the formula proposed in Villela and Matos (1975) (Equation 8). This is the most effective method of calculating the mean slope, as it considers several stretches along the longitudinal profile.

$S=\left(\frac{\sum \mathrm{L}_{\mathrm{i}}}{\sum\left(\frac{\mathrm{L}_{\mathrm{i}}}{\sqrt{\mathrm{D}_{1}}}\right)}\right)^{2}$

Where $\mathrm{S}$ is mean slope of the main channel. $\mathrm{L}_{\mathrm{i}}$ is the length in each section considered. $\mathrm{D}_{\mathrm{i}}$ is slope in each section considered.

To identify the tectonic influence on the evolution of the drainage network, tectonic tipping was observed in the basin, calculated from the Asymmetry Factor as proposed in Hare and Gardner (1985) and Keller and Pinter (1996) (Equation 9).

$\mathrm{AF}=100\left(\frac{\mathrm{A}_{\mathrm{dd}}}{\mathrm{A}_{\mathrm{d}}}\right)$

Where AF is Asymmetry Factor. $A_{d d}$ is right basin area (downstream direction). $A_{d}$ is Drainage Area. If the value is $\mathrm{AF}=50$ it means that a basin is symmetrical. However, if the value is greater than $\mathrm{AF}>5 \mathrm{O}$ it indicates that there was tilting to the left of the basin, if the value is less than $\mathrm{AF}<50$ the movement went to the opposite side. We propose three classes of asymmetry factor based on the characteristics of the sub-basins of the left bank of lower Rio Negro: 50 (symmetric basins); AF > 50 (asymmetric east-tilting basins (predominant); $\mathrm{AF}<50$ (asymmetric west-tilting basin (predominant).

\section{RESULTS AND DISCUSSION}

The calculated morphometric parameters for the Tarumã-Açu basin are shown in Table 2 and indicate the landforms and susceptibility to erosion in the basin: 


\begin{tabular}{cc}
\multicolumn{2}{c}{ Table 2 - Morphometric } \\
Parameters & Results \\
\hline Drainage Density & $2,2 \mathrm{~km} / \mathrm{km}^{2}$ \\
Stream Frequency & $0,3 \mathrm{~km}^{2}$ \\
Constant of Channel Maintenance & $0,4 \mathrm{~km} / \mathrm{km}^{2}$ \\
Minimum Altitude Value & $8 \mathrm{~m}$ \\
Maximum Altitude Value & $156 \mathrm{~m}$ \\
Relative Relief & $148 \mathrm{~m}$ \\
Basin Relief Ratio & $2,9 \mathrm{~m} / \mathrm{km}$ \\
Ruggedness Number & 325,6 \\
Infiltration Number & 0,7 \\
\hline
\end{tabular}

Source: the authors, 2020.

The drainage density is the main factor that controls drainage efficiency in the basin, associated with vegetation, geology (lithology and tectonics), mean rainfall, soil and the use and occupation (TOMAS and GOUDIE, 2000). The drainage density of the basin $\left(2.2 \mathrm{~km} / \mathrm{km}^{2}\right)$ is associated with the low dissection index of the basin, having a positive relationship with the relief energy (STEVAUX and LATRUBESSE, 2017), directly associated with low fluvial erosion (CASTRO and CARVALHO, 2009).

The Stream Frequency $\left(0.3 \mathrm{~km}^{2}\right)$ data indicates that erosive processes occur with a low intensity in the basin. The Constant of Channel Maintenance $\left(0.4 \mathrm{~km} / \mathrm{km}^{2}\right)$ of the basin has an inverse relationship with the drainage density; valid mainly for the first order channels (STEVAUX and LATRUBESSE, 2017). Regions with resistant rock, with high permeability soil or with dense forest cover should have a constant high channel maintenance and low drainage density (SAKTHIVEL et al., 2019). The result for the Tarumã-Açú basin indicates medium infiltration and permeability, good vegetation cover and relatively resistant rock type. According to Castro and Carvalho (2009, p. 06), the basin Ruggedness Number "shows the declivity relationship with the stream lengths, and the higher the number, more hillock and dissected relief (higher slopes) and streams more carved”. The number in the Tarumã-Açú basin is 325.6 indicating that the basin has hills and moderately dissected relief.

The Relief Ratio indicates the drainage efficiency of the basin (SANTOS et al., 2012). In the Tarumã-Açú Basin, the value is $2.9 \mathrm{~m} / \mathrm{km}$, indicating a low topographical gap and the low energy capacity of the Basin Rivers in the erosion and sediment transport processes, corroborating the low values of the Relative Relief $(148 \mathrm{~m})$. Infiltration is important to control basin runoff and is influenced by soil texture; soil structure; vegetal cover; biologic structures; antecedent soil moisture; conditions of the soil surface (MORISAWA, 1968). The infiltration number of the Tarumã-Açú basin is 0.7 , indicating a medium infiltration index. The basin soil is predominantly Latosol (WACHHOLZ et al., 2020), this soil type has a low infiltration coefficient (VIEIRA, 2008), in addition, except for the southern portion, the vegetation of the basin has not been deforested (WACHHOLZ et al., 2020), the mentioned parameters decrease the infiltration rate in the basin.

In the Tarumã-Açú basin, the topographic elevations below $30 \mathrm{~m}$ refer to the lower Tarumã-Açú river and some tributaries indicate channels (water mirror). The topographic elevations of 30-60 m can indicate areas of igapó forest, mainly in the areas bordering the channels and the topographic elevations greater than $90 \mathrm{~m}$ can indicate dividers (Figure 3). 


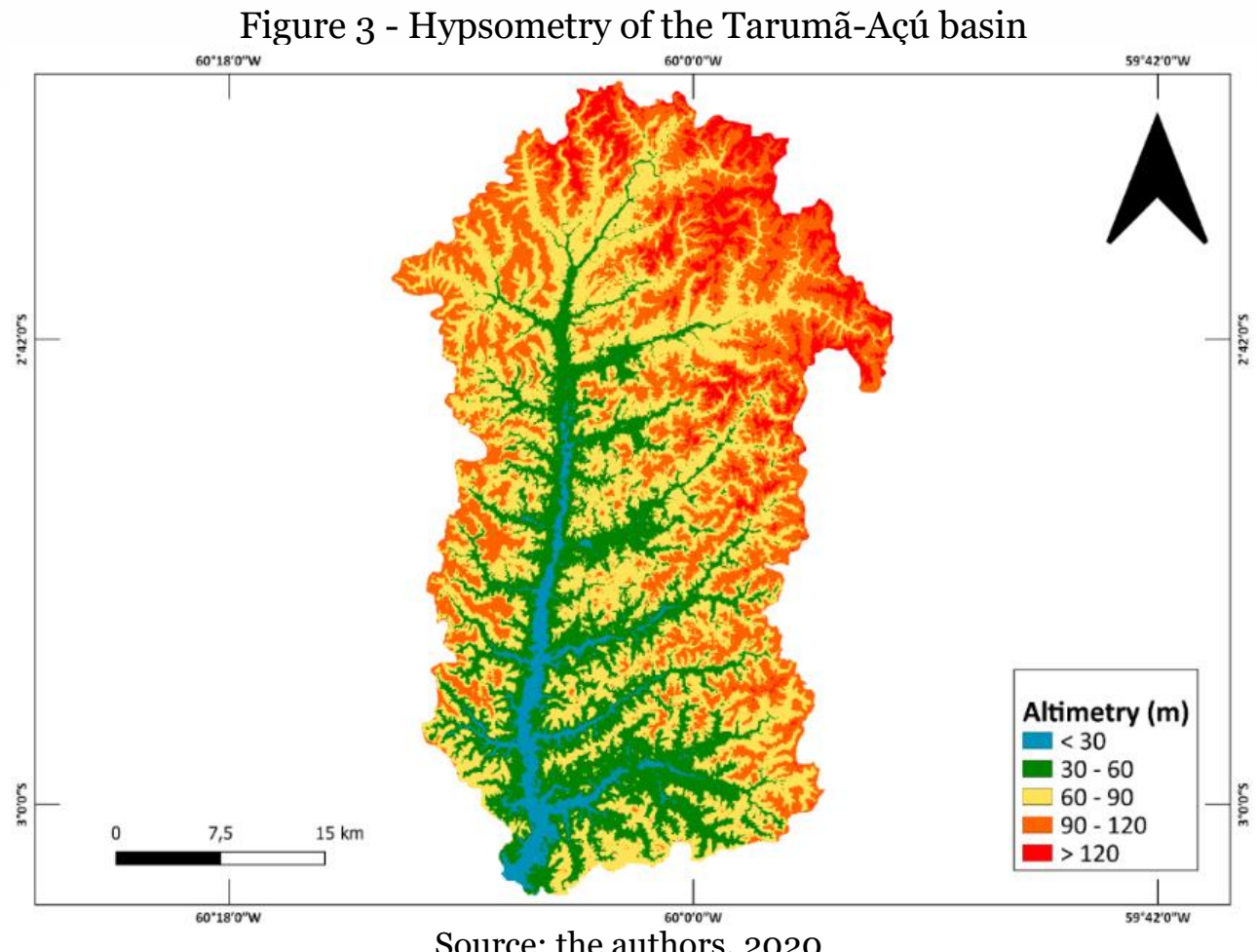

The slope data for the Tarumã-Açú basin is $119.6 \mathrm{~km}^{2}$ (0-3\%), $446.9 \mathrm{~km}^{2}(3-8 \%), 616.9$ $\mathrm{km}^{2}$ (8-20\%), $167.4 \mathrm{~km}^{2}$ (20 -45\%), $1.0 \mathrm{~km}^{2}$ (45-75\%) (Figure 4). Most of the basin has slopes between $3 \%$ and $20 \%\left(1063,7 \mathrm{~km}^{2}\right)$, indicating a smooth wavy and wavy slopes. The flat slope is located near the mouth of the Tarumã-Açú river and the largest slopes indicate terraces and dividers. Most of the basin is characterized by small and medium hills (3-20 \%) (SARGES et al., 2011; VIEIRA, 2008).

Figure 4 - Slope in Tarumã-Açú Basin

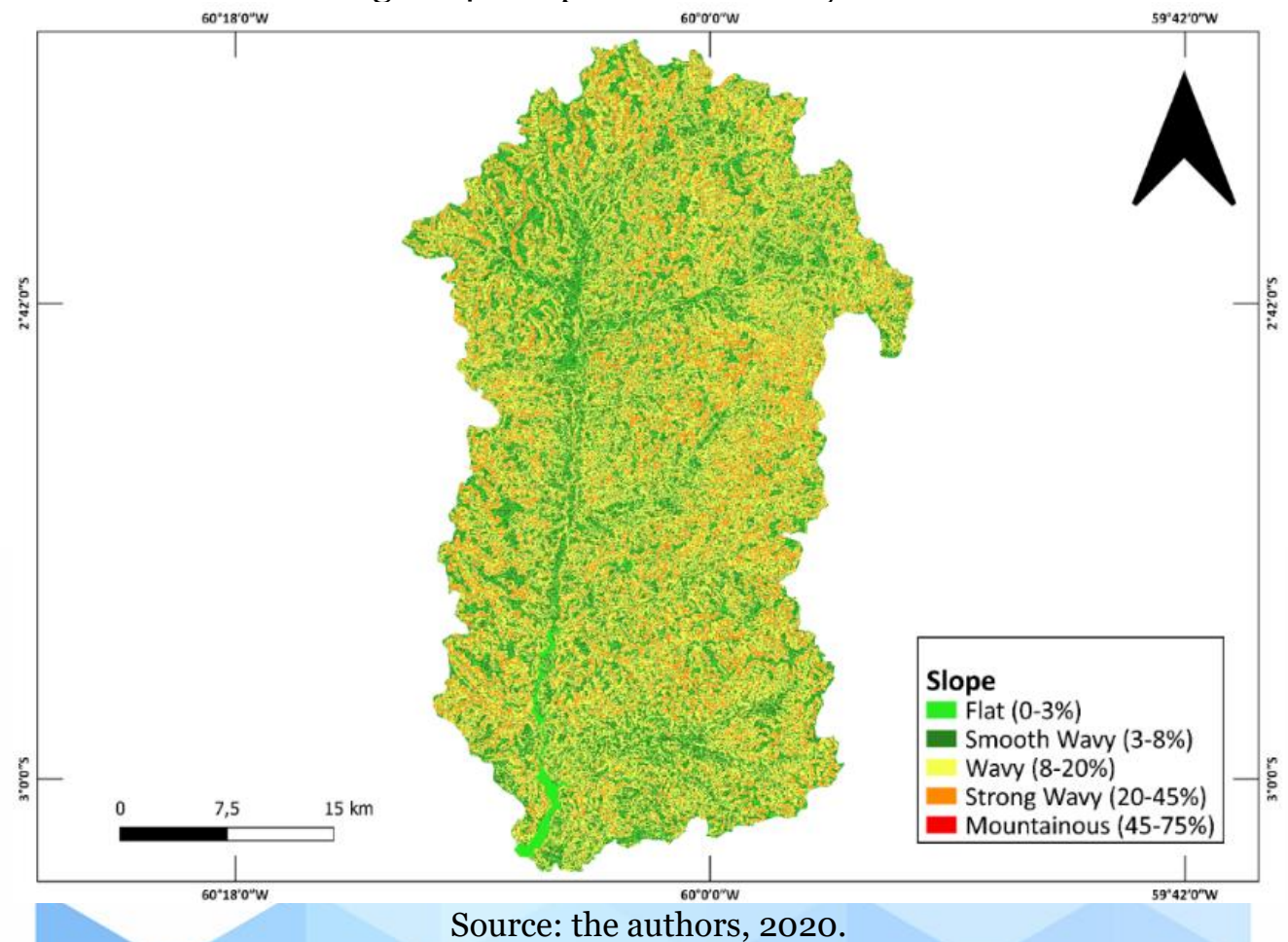

Matheus S. de Queiroz, José Alberto L. de Carvalho. Geomorphological characterization of the Tarumã-Açú basin, Amazonas, Brazil Brazilian Geographical Journal: Geosciences and Humanities research medium,

Ituiutaba, v. 11, n. 2, p. 113-125, ago./dez. 2020 
The Tarumã-Açú River has a slope of $0.00153 \mathrm{~m} / \mathrm{m}$, indicating a low slope along the main channel of the basin. In the last $16 \mathrm{~km}$ of the river, the slope is $0.00001 \mathrm{~m} / \mathrm{m}$ with topographic amplitude of $2 \mathrm{~m}$. The influence of the backwater effect by the Negro river in the Lower Tarumã-Açú River (SIQUEIRA, 2019), drowning the valley and forming a fluvial ria with sedimentation characteristics. The low topographic amplitude, backwater effect and possible tectonic influence are factors that characterize the longitudinal profile of the TarumãAçú river (Figure 5).

Figure 5 - longitudinal profile of the Tarumã-Açú river

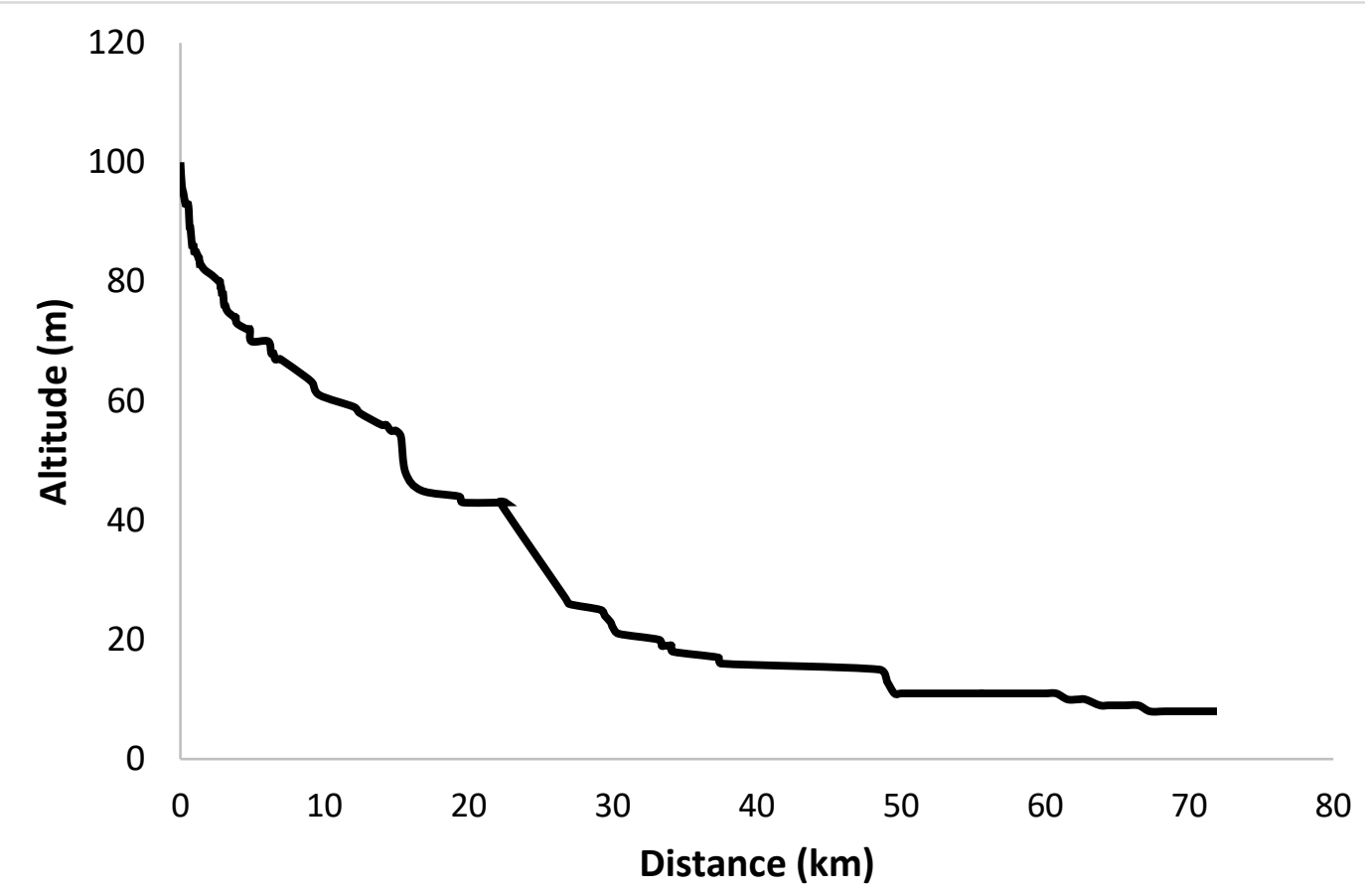

The profile was calculated based on images from the SRTM mission. Source: the authors, 2020.

The altimetric differences that occur, mainly, in the middle Tarumã-Açú river may indicate the presence of knickpoints in the basin, as observed in some tributaries of the main channel (GOIABEIRA et al., 2020). These topographical differences can indicate tectonic control in the basin, it is also possible to identify drainage anomalies such as anomalous curves and drainage inflections (elbows).

The asymmetry factor of the Tarumã-Açú basin is 28.4 , confirming the tectonic tilting to the west in the basin. This confirms the tectonic influence on the drainage morphology of the Tarumã-Açú basin, possibly during the Cenozoic. The basins on the left bank of the lower Negro river (Cuieiras, São Raimundo) also tectonic tilting to the west, however the TarumãMirim basin tends to tectonic tilting to the east (SILVA, 2005; QUEIROZ, 2020).

The tributaries of the Tarumã-Açú river have lineaments that may indicate tectonic control in these tributaries (probably Dip-Slip faults) on the left bank of the Tarumã-Açú river indicating an en echelon system (Figure 6). This work does not present structural data to support the hypothesis of parallels Dip-Slip faults, using only remote sensing data (lineaments by radar images, analysis of the drainage network and parallelism of river channels). 
Figure 6 - Structural features of the Tarumã-Açú basin

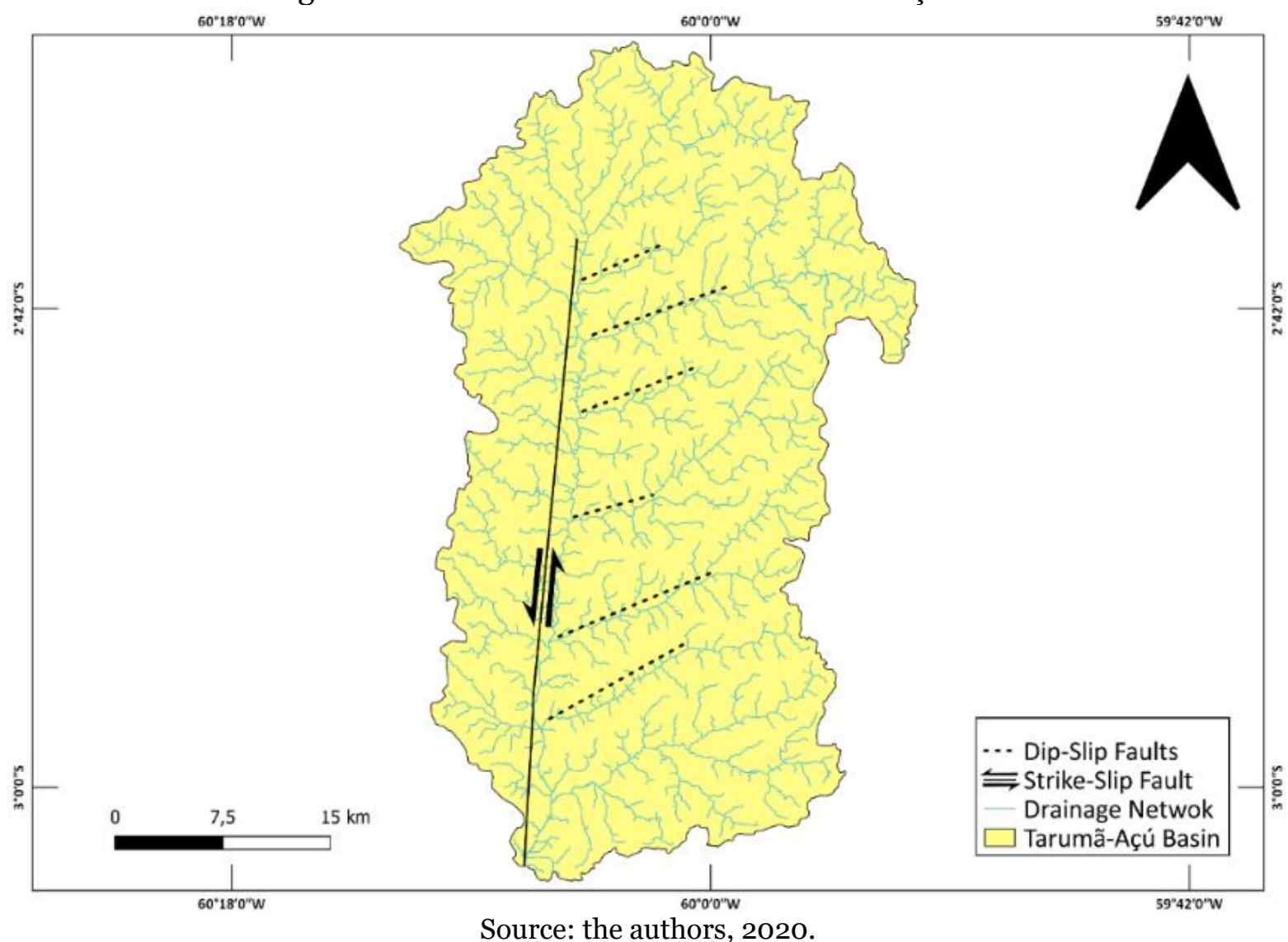

\section{CONCLUSION}

The morphometric parameters of the Tarumã-Açú basin indicate that the relief has a low susceptibility to erosion. Topographic elevations of 30-60 m may indicate areas of igapó forest, mainly in the areas bordering the channels. Topographic elevations greater than $90 \mathrm{~m}$ may indicate dividers and the low topographic amplitude corroborates the susceptibility data to erosion in the basin. Slope data indicates that the flat slope is located near the mouth of the Tarumã-Açú river, the Strong Wavy and Mountainous slopes (20-75\%) indicate terraces and dividers and most of the basin is characterized by small and medium hills (3-20 \%).

The basin has possibly a strong structural control represented by a Strike-Slip Fault that controls the Tarumã-Açú River and lineaments (Probably Dip-Slip Faults) that control the tributaries on the left bank. It is also noted that the basin underwent tectonic tilting to the west, possibly indicating tectonic influence during the Cenozoic. Therefore, it can be said that tectonics is an important factor for the compartmentalization of the morphology of the Tarumã-Açú basin.

\section{REFERENCES}

ALBUQUERQUE, O.R. Reconhecimentos geológicos no vale do Amazonas, Rio de Janeiro. DNPM, Boletim do Serviço Geológico e Mineralógico do Brasil 3, p. 84, 1922.

BEZERRA, P.E.L. Compartimentação morfotectônica do interflúvio Solimões - Negro. 2003. 194f. Dissertação (Mestrado em Geociências), Universidade Federal do Pará, Belém. 
CAPUTO, M.V. Stratigraphy, tectonics, paleoclimatology and paleogeography of northern basins of Brazil. 1984. 583 p. PhD thesis, University of California, Santa Barbara,

CASTRO, S.B.; CARVALHO, T.M. Análise morfométrica e geomorfologia da bacia hidrográfica do rio Turvo - GO, através de técnicas de sensoriamento remoto e geoprocessamento. Scientia Plena, Vol. 5, 2009.

CHANDRASHEKAR, H.; LOKESH, K.V.; SAMEENA, M.; ROOPA, J.; RANGANNA, G. GIS Based Morphometric Analysis of Two Reservoir Catchments of Arkavati River, Ramanagaram District, Karnataka. Aquatic Procedia, vol. 4, p. 1345 - 1353, 2015.

CHRISTOFOLETTI, A. Geomorfologia Fluvial. São Paulo: Edgard Blucher, 1981. vol. 1. 313 p.

CHRISTOFOLETTI, A. Geomorfologia. São Paulo: Edgard Blucher, 1980.

COSTA, A.R.A. Tecônica Cenozóica e a Movimentação Salífera na Bacia do Amazonas e suas Relações com a Geodinâmica das Placas da América do Sul, Caribe, Cocos e Nazca. 2002. 238f. Dissertação (Mestrado em Geociências), Universidade Federal do Pará, Belém.

COSTA, J. B. S.; BEMERGUY, R. L.; HASUI, Y.; BORGES, M. S ; FERREIRA JÚNIOR, C. R. P. ; BEZERRA, P. E. L.; COSTA, M. L.; FERNANDES, J. M. G. Neotectônica Da Região Amazônica: Aspectos Tectônicos, Geomorfológicos e Deposicionais. Geonomos, Belo Horizonte, v. 4, n. 2, p. 23-44, 1996.

COSTA, R.C.R.; FILHO, N.T.; OLIVEIRA, A.A.B. Geomorfologia. Folha SA.20 - Manaus. In PROJETO RADAMBRASIL (Levantamento de Recursos Naturais). Rio de Janeiro: MME/DNPM. v.18, p.169-231. 1978.

EMBRAPA, Centro Nacional de Pesquisa de Solos. Sistema Brasileiro de Classificação de Solos. Brasília: EMBRAPA Produção de Informação; Rio de Janeiro: EMBRAPA Solos, 2006.

FERREIRA, A.; RIGUETI, A.; BASTOS, G. Bacia do Amazonas: Sumário Geológico e Setores em Oferta. 13 ${ }^{\text {a }}$ Rodada de Licitações de Petróleo e Gás, 2015.

FRANZINELLI, E.; IGREJA, H.L.S. Modern sedimentation in the Lower Negro river, Amazonas State, Brazil. Geomorphology, 44, 259 - 271, 2002.

FRANZINELLI, E.; IGREJA, H.L.S. Utilização de sensoriamento remoto na investigação da área do Baixo Rio Negro e Grande Manaus. VI Simp. Bras. Sens. Rem. An. 3, p. 641 - 648, 1990.

FRANZINELLI, E.; IGREJA, H.L.S.; REPOLHO, T. Fragmentation of Ecosystem Owing to Neotectonics in the Amazon Basin. Sci. Rep. Tohoku Univ., 7th Ser. (Geogr.), 49 (2), p. $207-214,1999$.

GOIABEIRA, C.V.S.; BARBOSA, C.R.; ABREU, G.B.A; SILVA, P.C.V.; QUEIROZ, M.S. Análise Bacteriológica Da Água Na Cachoeira Do Tarumã-Açu, Manaus-Am. In: ALBUQUERQUE, C. C.; BATISTA, I. H. (Org.). VII Workshop Internacional Sobre Planejamento e Desenvolvimento Sustentável em Bacias Hidrográficas. 7ed.Boa Vista: UFRR, v. 1, 2020.

HARE, P.W.; GARDNER, T.W. Geomorphic Indicators of Vertical Neotectonism along Converging Plate Margins, Nicoya Peninsula, Costa Rica. In: MORISAWA, M.; HACK, J.T. (Eds). Tectonic Geomorphology. Proceedings of the 15th Annual Binghamton Geomorphology Symposium, Allen and Unwin, Boston, 123-134, 1985. 
HOORN, C.; GUERRERO, J.; SARMIENTO, G.; LORENTE, M. Andean tectonics as a cause for a changing drainage patterns in Miocene northern South America. Geology. v. 23, p. 237-240, 1995.

HOORN, C.; RODDAZ, M.; DINO, R.; SOARES, E.; UBA, C.; OCHOA-LOZANO, D.; MAPES, $\mathrm{R}$. The Amazonian Craton and its influence on past fluvial systems (Mesozoic-Cenozoic, Amazonia). In: HOORN, C.; WESSELINGH, F. (Eds.). Amazonia: Landscape and Species Evolution. Wiley - Blackwell, p. 103-122, 2010.

HORBE, A.M.C.; NOGUEIRA, A.C.R.; HORBE, M.A.; COSTA, M.L.; SUGUIO, K. A lateritização na gênese das superfícies de aplanamento da região de Presidente Figueiredo Balbina, nordeste do Amazonas. In REIS, J.; MONTEIRO, M.A.S. (Orgs.). Contribuições à geologia da Amazônia. v. 2, p. 148-176. 2001.

HORN, B. K. P. Hill Shading and the Reflectance Map. Proceedings of the IEEE, 69:1447, 1981.

HORTON, R. E. Erosional development of streams and their drainage basins: hydrophysical approach to quantitative morphology. Geol. Soc. America Bulletin, Vol. 56, p. 275-370, 1945.

HORTON, R.E. Drainage basin characteristics. Transition of the America Geophysical Union, vol. 13, p. 350-361, 1932.

IGREJA, H.L.S., Aspectos do modelo neotectônico da placa Sul-Americana na província estrutural Amazônica, Brasil. 1999. Tese, Universidade do Amazonas, Manaus (unpublished).

KELLER, E., PINTER, N. Active tectonics: earthquake, uplift and landscape. 1a. ed. New Jersey: Prentice Hall, 1996. 338p.

KISTLER, P. Historical Resumé of the Amazon Basin. Belém, PETROBRAS-RENOR, (Relatório Técnico Interno, 104-A), 1954.

LATRUBESSE, E.M; FRANZINELLI, E. The late Quaternary evolution of the Negro River, Amazon, Brazil: Implications for island and floodplain formation in large anabranching tropical systems. Geomorphology 70, p. 372-397, 2005.

MAPES, R.W.; NOGUEIRA, A.C.R.; COLEMAN, D.S.; VEGA, A.M.L. Evidence for a continent scale drainage inversion in the Amazon Basin since the Late Cretaceous. In GSA PHILADELPHIA ANNUAL MEETING, USA, 2006.

MEIS, M.R.M. Upper Quaternary process of the middle Amazon area. GSA Bull. v. 82, p. 1073-1078. 1971.

MORISAWA, M.E. Strems: Their dynamics and morphology. McGraw-Hill Book, New York, 1968.

MUÑOZ; V. A.; VALERIANO, M.M. Estimativa da Amplitude Topográfica por Geoprocessamento de Dados SRTM para Modelagem do Relevo. GEOGRAFIA, Rio Claro, v. 36, n. 1, p. 107-120, 2011.

QUEIROZ, M.S. Evidências de Neotectônica na Bacia Hidrográfica do Mindu - Manaus Amazonas. Revista Tocantinense de Geografia, v. 9, n. 18, p. 130-142, 2020.

REIS, N. J; ALMEIDA, M.; RIKER, S. L; FERREIRA, A. L. Geologia e Recursos Minerais do Estado do Amazonas. CPRM - Serviço Geológico do Brasil, Manaus, 2006.

SAKTHIVEL, R.; JAWAHAR RAJ, N.; SIVASANKAR, V.; AKHILA, P.; OMINE, K. Geo-spatial technique-based approach on drainage morphometric analysis at Kalrayan Hills, Tamil Nadu, India. Appl Water Sci 9, 24, 2019. 
SANTOS, A. M.; TARGA, M. S.; BATISTA, G. T.; DIAS, N. W. Análise morfométrica das subbacias hidrográficas Perdizes e Fojo no município de Campos do Jordão, SP, Brasil. AmbiAgua, Taubaté, v. 7, n. 3, p. 195-211, 2012.

SARGES, R.R.; SILVA, T.M.; RICCOMINI, C. Caracterização do Relevo da Região de Manaus, Amazônia Central. Revista Brasileira de Geomorfologia, v. 12, nº 1, 2011.

SCHUMM, S. A. The evolution of drainage system and slopes in badlands at Perth Amboy, New Jersey. Bulletin of the Geological Society of America, vol. 67, p. 597-646, 1956.

SILVA, C.L. Análise da tectônica Cenozóica na região de Manaus e adjacências. 2005. Tese (geologia regional, Instituto de Geociências e Ciências Exatas da Universidade Estadual Paulista (Unesp), Rio Claro.

SILVA, C.L.; ROSSETTI, D.F. História Geológica dos Rios na Amazônia. Ciência e Cultura, vol.61, no.3, São Paulo, 2009.

SIQUEIRA, L.F. Estudo Hidrológico do Efeito de Barramento Hidráulico do Rio Tarumã-Açú, Manaus-Am. 2019. Dissertação (Programa de pós-graduação em Clima Ambiente do INPA) Manaus.

STERNBERG, H.O. Vales Tectônicos na Planície Amazônica?. Revista Brasileira de Geografia, n. 4, 1950.

STEVAUX, J.C; LATRUBESSE, M. E. Geomorfologia Fluvial. Oficina de Textos: São Paulo, 2017.

SURESH, D.; COLINS, J.; JAYAPRASAD, B.K. Identification of Artificial Recharge Sites for Neyyar River Basin. International Journal of Remote Sensing \& Geoscience (IJRSG), Vol. 4, Issue 3, 2015.

TOMAS, C.R.; GOUDIE, A. The Dictionary of Physical Geography. Blackwell Publishers, $3^{\circ}$ edition, Malden, USA, 2000.

TRICART, J. Aperçu sur le Quaternaire Amazonien. Annais de Geographie. v. 473, p. 1-54. 1977.

VIEIRA, A.F.G. Desenvolvimento e Distribuição de Voçorocas em Manaus (AM): Principais Fatores Controladores e Impactos Urbano-Ambientais. 2008. Tese (Programa de Pós-Graduação em Geografia, Universidade Federal de Santa Catarina - UFSC), Santa Catarina.

VILLELA, S. M; MATTOS, A. Hidrologia aplicada. São Paulo: McGraw-Hill do Brasil, 245 p., 1975 .

WACHHOLZ, F.; COLARES, I. S.; FERREIRA JUNIOR, J. C.; MAIA, S. A. Caracterização Física e Socioeconômica da Bacia Hidrográfica do Rio Tarumã-Açú - Amazonas. In: ALBUQUERQUE, C. C.; BATISTA, I. H. (Org.). VII Workshop Internacional Sobre Planejamento e Desenvolvimento Sustentável em Bacias Hidrográficas. 7ed.Boa Vista: UFRR, v. 1, p. 592-600, 2020.

Recebido em: 23/09/2020. Aprovado para publicação em: 28/12/2020. 